\title{
Leadership through theological education: Two case studies in South African history
}

\author{
G A Duncan \& J W Hofmeyr
}

(University of Pretoria)

\begin{abstract}
Leadership through theological education: Two case studies in South African history
\end{abstract}

The quality of visionary leadership requires serious attention in current South Africa, both because of its importance but also sometimes because of the lack of leadership in church and theological contexts. In the first section of this article, focus is placed on leadership in the Faculty of Theology (NG Kerk) at the University of Pretoria, and in the second section, on the leadership at the Lovedale Missionary Institution in the Eastern Cape. Finally, some comparisons and conditions are drawn.

\section{INTRODUCTION}

The quality and context of leadership requires serious consideration in contemporary South Africa, not only because of its importance but also because it is sadly lacking in church and academic circles, and also within the spheres of theological education in South Africa. In this article the focus is placed, first on the leadership of the Faculty of Theology of the Dutch Reformed Church (Nederduitse Gereformeerde Kerk) at the University of Pretoria, and secondly on the leadership of the principals of the non-denominational Lovedale Missionary Institution in Alice in the Eastern Cape. In a third subsection, some comparisons are drawn between the above case studies, together with some concluding remarks.

\section{LEADERSHIP AT THE FACULTY OF THEOLOGY (NEDER-DUITSE GEREFORMEERDE KERK: 1938 - 2002) AT THE UNI-VERSITY OF PRETORIA}

\subsection{High academic standards and proper education}

The founding of the Faculty of Theology of the Dutch Reformed Church at the University of Pretoria has a long and specific history on which we cannot focus here. Suffice to say that it was eventually established in 1938, and four professors were appointed in the four departments i e Old Testament Studies (Prof J H Kritzinger), New Testament Studies (Prof E 
P Groenewald), Dogmatics (Prof G M Pellisier) and Church History and Church Polity (Prof D J Keet).

When the Dutch Reformed Church (DRC) Faculty of Theology was established at the University of Pretoria in 1938, the structural and organisational model was used that of the Free University of Amsterdam in the Netherlands. In essence it boiled down to a "simplex ordo" system of theological education. Next to Old and New Testament Studies and Church History, Dogmatics was also included as one of the official university courses. In the course of the following two decades this situation was consolidated when Missiology and Practical Theology were also recognised as university disciplines. It was however, only during the 1960s that the latter two disciplines developed into two separate departments.

From 1938 onward the Faculty of Theology at the University of Pretoria had a dual structure, consisting of a so-called section A of the Nederduitsch Hervormde Kerk (NHK) and a so-called section B of the Nederduitse Gereformeerde Kerk (DRC). This was the result of nontheological and non-academic considerations. This was indeed, according to Wethmar (2000:422) "a pragmatic arrangement, to solve a complex situation, rather than a well considered, or in terms of a philosophy of science, well-founded construction". The differences between these two churches were predominantly concerned with politics, culture, spirituality and general religious attitude. For a period of more than 60 years, the curriculum for the training of theological students for the ministry consisted of three parts. The first three years were devoted to the study for a BA degree during which at least two years of study in each of the two biblical languages was required. To these were added subjects in the arts, humanities and social sciences. After this followed a BD degree over a further period of three years. During a seventh year a postgraduate diploma course was followed, focusing on ministerial formation.

In the early 1980s the Faculty of Theology, after lengthy negotiations with the denominational body, implemented a so-called integrated course, in which the previous BA and BD degrees were integrated. This integration was effected by introducing biblical and theological studies in the first degree. It had the advantage that it proved beneficial for the motivation of the students, but the disadvantage was that the undergraduate theology course became so diverse that it tended to be didactically cumbersome.

With regards to the theological direction of the Faculty of Theology at the University of Pretoria, it developed a very strong exegetical tradition, especially under the leadership of one of its earlier deans, Professor E P Groenewald. He was influenced both by his studies in the 
Netherlands but also by the Du Plessis case at Stellenbosch. This called for a serious and responsible reconsideration of biblical studies in the 1930s and thereafter. Eventually, however, this exegetical tradition was at times overemphasised to such a degree that it not only caused tensions but also an imbalance with regards to a comprehensive theological foundation, both in teaching and in research. To what extent this faculty succeeded in forming and developing a reformed spirituality amongst its students, remains to be seen in a more focused study on this issue. Sad to say however, the general impression remains that especially in later years this dimension of theological and spiritual formation did not receive proper attention. In the course of time it seems to have become an even greater lacuna.

\subsection{Strong denominational emphasis}

The Faculty of Theology at the University of Pretoria from its beginnings, had a very strong denominational focus. This was not an uncommon phenomenon in either the Netherlands or in South Africa in those times. A very specific contract was drawn up between the university and the denomination. This provided for both the needs of the university and the church regarding academic requirements and ministerial development. The reality of a strong denominational emphasis was not untypical of the decades which followed the establishment of the Faculty of Theology. On the contrary, it even developed into a rather fierce battle between the DRC and the NHK about questions such as the names and origin of these churches in South Africa. A strong polemical and apologetic trend developed amongst these churches. It was eventually deans like Proff B J Marais, J A Heyns and A B du Toit who made a major contribution towards a more open and a more ecumenical orientation in the Faculty of Theology. It was especially B J Marais in the 1950s and 1960s who, in spite of sharp criticism raised against him over racial and ecumenical issues, paved the way for a greater understanding in the South African context, but also at the Faculty of Theology in Pretoria. Fortunately, from the 1990s a greater awareness of ecumenicity developed. In the appointment of faculty officials, like the dean, deputy dean and the heads of departments, the involvement of a particular church has always been taken into account.

The participating churches would in future deal with their common interests in the faculty through the mechanism of an Ecumenical Advisory Board. This Board has an advisory function and does not make binding decisions. In cases where particular posts are allocated to specific churches, in terms of the agreement of the university with such a church, that church may have representation on the university committee dealing with such an appointment. 
As Wethmar (2000:426) rightly states the ecumenical nature of theology and theological education can be related to the catholicity of the church. Theological truth is closely related to this catholicity. On the other hand, catholicity is dependent on the ultimate eschatological truth being envisaged and constantly aimed at. This truth, however, cannot be reached in this dispensation in a final consensus.

It is, however, important to take note of the fact that ecumenicity in this case is not indicative of confessional indifference. It does not imply non-denominationality, but rather denominations in dialogue. This again implies that each participating church could have its students educated without alienating them from their church tradition, while simultaneously they could be trained to cope with the demands of being church in a plural society.

\subsection{Exclusive cultural, racial and sexual orientation}

As much as the Faculty of Theology at the University of Pretoria had a strong denominational focus, it also had in the first six decades of its history a strong cultural and racial orientation.

It has to be said that during the $19^{\text {th }}$ century an Afrikaner theology developed which would gradually produce a segregated society and sanctioned it when it took form. The Bible was the document where justification was found for the paternalistic role of the Afrikaner in South Africa. In the middle part of the $20^{\text {th }}$ century suggestions and came over as true racists, they were honest in trying to interpret Scriptures. There was also a strong interplay between the needs, fears and emotions of the general public after the South African War recommendations from members of the NGK paved the way for various apartheid laws. Although they came over as true racists, many were honest in trying to interpret the Scriptures. There was also a strong interplay between the needs, fears and emotions of the general public after the South African War and the Depression period.

During the negotiations in the 1990s between the then existing two sections of the Faculty of Theology serving the Nederduitse Gereformeerde Kerk (NGK) and the Nederduitsch Hervormde Kerk (NHK) the NGK and its faculty were perceived to be that of a legalistic reformed orthodoxy, a pietistic or charismatic tendency and so-called left wing political sympathies. Likewise the NHK and its faculty were perceived to be a liberal theology and right wing political attitudes. "These perceptions were not new, but merely a reflection of a century and a half of controversies and misunderstanding between two groups of people in the same nation" (Wethmar 2000:422). It was naturally in the period between 1938 and 1990 to operate in an exclusive mode of cultural and racial separation, and in that respect the faculty at the 
University of Pretoria was no exception. On the one hand it must be remembered that the year of the establishment of the Faculty was also the centenary year of the Great Trek, and therefore also a celebration of Afrikaner nationalistic sympathies. On the other hand various professors and even deans of the Faculty of Theology were either instrumental in developing and furthering an apartheid theology (especially proff. E P Groene-wald and A B du Preez), or acting as prophets in opposing a scriptural foundation of the apartheid policy (B J Marais). Though all of them were in many senses children of their times, they allowed themselves to be used and maybe even abused by various constituencies. The general pattern was that NGK people of colour would receive their theological education at separate theological schools or so-called black universities.

As much as the University of Pretoria and the NG Kerk remained in many senses a bastion of Afrikaner nationalism late into the 1970s and even into the 1980s, in spite of various critical voices, that remained the case at the theological faculty as well. However one of the strong voices beginning to raise serious questions with regards to the continuation of an exclusive cultural and racial orientation came from somebody who was very much part of the Dutch Reformed Church (NG Kerk) and the Afrikaner establishment i.e. professor J A Heyns.

Since the 1960s various attempts were indeed made to do soulsearching and to question the status quo. A growing number of concerned people were raising their voices. Also in the circles of the Faculty of Theology these voices were heard. It started with the unpopular criticism of B J Marais even since the 1950s. Later on, in the 1970s, the voice of people like J A Heyns and A B du Toit were in contrast to that of a dean like Professor C W H Boshoff, who had more sympathy for the status quo and the specific needs of the Afrikaner people.

With regard to the inclusion of women students into the fold of theological training at the University of Pretoria it is a matter of largely following suit with the church policies of the time. Although women were only allowed to become ministers from 1990, they had been in the course of the years allowed to study theology. That was, however, rather the exception than the rule. From the 1990s the number of women students however steadily increased.

\subsection{A period of transition}

The period 1989 to 2002 can be seen as a period of transition for the Faculty of Theology of the Dutch Reformed Church. It is well-known that the 1990s in South Africa were characterised by a comprehensive political transformation. A new constitution for the country came into being and this gave rise to new legislation also in the field of education. 
The deanship of professor W S Prinsloo, running from 1989 to 1996, will probably best be remembered for its good administration and also its strong initiatives in concluding co-operation agreements with smaller seminaries of other church denominations. This was the first step towards the ecumenical expansion of the faculty. Prinsloo's deanship will, however, also be remembered by some for the overemphasis on the biblical subjects at the detriment of the rest of the theological corpus. The lack of a comprehensive theological foundation concerning the formative subjects has, because of this and other reasons, filtered through into the church. The church is already paying dearly for its lack, amongst other things, of a strong missiological, confessional, and historical foundation.

In conjunction with a tendency towards superficiality, which is often typical of younger countries and societies, this is going to challenge the Dutch Reformed Church to seriously reconsider its position with regard to its tradition and vision. The Dutch Reformed Church has to decide which way it wishes to go: either that of a human organisation which is run on business principles, or otherwise a soundly rooted part of the body of Christ, which wishes to be relevant for its times and its people.

Professor C J Wethmar became dean of the Faculty of Theology in 1997. He stressed the expansion of ecumenical relations in South Africa as well as abroad together with a greater racial openness. In the international forum various international agreements were entered into, and Wethmar also visited some of the traditional collaborative partners in Europe and the Far East. Under his leadership and guidance, local ecumenical relations with the South African Council for Theological Education (SACTE) were forged, but also the first steps were taken to establish a multi-denominational Faculty of Theology at the University of Pretoria.

Because of the political changes in South Africa, and in the field of higher education, a restructuring of the theological faculty at the University of Pretoria clearly became inevitable. After lengthy internal negotiations between the previous two sections of the faculty, (i e the Nederduitsch Hervormde Kerk van Afrika (NHK) and the Nederduitse Gereformeeerde Kerk (DRC) the final decision was taken on 17 August 1999 to form a single Faculty of Theology from the beginning of 2000. The goal was one which would be racially more representative, and one in which different churches could work together, but in such a way that each church tradition concerned could develop in its own right.

In the meantime, two important postgraduate courses were established at the faculty, which proved to fulfil a great need. The first is a MPhil degree in Applied Theology. In this way persons in possession 
of a Bachelors degree or equivalent qualification in any non-theological direction could enhance their knowledge of theology, whether for professional or personal reasons. The second is the $\mathrm{PhD}$ degree in Theology, which is a doctorate through specialized research. It is proving to be very popular, particularly among international students.

In the year 2000 Professor C J A Vos became the dean of the newly established multi-denominational Faculty of Theology at the University of Pretoria. It was under his sensible leadership and congenial openness that the newly created Faculty of Theology took its first steps in becoming a very successful exercise in multi-denominational cooperation, and in becoming racially more inclusive. In 2002 the Uniting Presbyterian Church of Southern Africa joined the faculty as the third partner, bringing in a large component of English speaking and black students. This development was met with great enthusiasm and in spite of language and cultural differences, it is proving to be very successful and enriching.

In the meantime, the faculty still excels with a high research output and extensive international co-operation and networking. Various prominent honorary professors were appointed in the faculty, i.e. Professors J van Oort (Utrecht), G Heitink (Amsterdam), E Otto (München) and H J Klauck (Chicago) as well as Bishop M Dandala (presiding Bishop of the Methodist Church in Southern Africa). In cooperation with the Faculty of Economic and Management Sciences, the Desmond Tutu Chair in Leadership Development and future Studies was established.

Students are taught to be independent, creative and critical in their thinking and actions. They are also trained to be well-equipped ministers of religion. The faculty wishes to be a true home for lecturers and students, and it is in this context that students learn on the basis of a firm faith, to be responsible and well-balanced members of society.

\section{LEADERSHIP AT THE LOVEDALE MISSIONARY INSTITUTION (1841-1920)}

\subsection{Introduction}

The Lovedale Missionary Institution was established in 1841 in the Alice area of the Eastern Cape. It was a venture of the Glasgow Missionary Society (Presbyterian) and one of its aims was to train African students for the ministry.

The work of theological education at Lovedale cannot be separated from the principals of the Institution under whose direction it was carried out. Despite policy differences amongst these dynamic leaders, there was 
a remarkable degree of continuity in and consolidation of the principles which guided their endeavours as already stated in 1906:

"Lovedale has been exceedingly fortunate in its long history, now extending over sixty years and having during that period only two principals to direct its development and guide its growth. There has thus been preserved a remarkable continuity in its policy" (Christian Express XXXVI, 425; cf South African Outlook, LIV, 647).

The third principal, James Henderson, certainly maintained this tradition.

It was clear from the beginning of mission work at Lovedale, that ex-patriate missionaries could not cope with the volume of work necessary to convert the peoples of the southern tip of the African continent and further afield. So it was that leadership skills had to be developed among the local people for various types of ministry with the ultimate aim of converting black people.

\subsection{Rev William Govan (1841-1870)}

From the inception of mission work at Lovedale, the task of preparing expounders of the gospel was prefigured. At the opening ceremony of the Lovedale Seminary on $21^{\text {st }}$ July 1841 , Rev WR Thomson preached on the text: "And he ordained twelve, that they should be with Him, and that He might send them forth to preach" (Mk 3:14). This was to be achieved by the preparation of teachers, evangelists, mission agents and pastors.

The first principal, Rev William Govan was fully committed to the training of ministers. He based his work on four principles. Education at Lovedale was to be interdenominational, racially integrated, of a high academic standard, and a stress was laid on the need for conversion (which was synonymous with education). However, the fulfillment of Govan's vision was curtailed by the frequent Wars of Dispossession and the "cattle-killing" process in the Eastern Cape until the late 1850s. His ability to discern leadership potential was realised and confirmed by his decision to take the young Tiyo Soga to Scotland, where he trained as a minister of the United Presbyterian Church of Scotland. Shepherd (1971:18) comments appropriately: "Tiyo Soga became the first thoroughly educated and ordained missionary to his own race, and in his all-too-brief career did magnificent work."

Govan's approach to leadership training was that black people should be trained to the same level as white candidates, and that they should, therefore, be able to function on the same level as a result of his perception of the course of racial integration. Consequently, he intro- 
duced a classical course which was a replica of that offered in Scotland at that time. His experience with Tiyo Soga led him to believe that a select group of blacks could be educated to the highest level of classical attainment. They would then become role models for others who might follow, as well as to those who might occupy other orders of ministry i.e. evangelists, mission agents and teachers. This led to a direct clash with his successor, James Stewart, and, eventually to his resignation.

Stewart favoured the general education of the majority of the people, with an emphasis on teachers and preachers. He struggled with the idea that blacks could attain the same levels as whites, though he made provision for "any others who might wish something else" (Shepherd 1971:29). That something else was ordination, a matter that was to lead in time to serious breaches within the Scottish and other missions. Stewart's (1906:370) sincerely held view was that black people were 'infants' and would require guidance for many years before being able to compete on an equal footing with white people:

"In the advance of the African races there is one danger ahead. It is the over- confidence and satisfaction with themselves displayed by so many of those who have been partially educated; and the entirely wrong impression, many of them seem to entertain, that it is possible for them to reach in one or two generations the level which other races have taken long centuries to reach. From this fallacious conclusion they are apt to claim equality, for which as a race they are not yet prepared."

He held that his view represented the "essential" aim of education, while Govan's represented the "accidental" one. Therefore, leadership exercised by black evangelists and teachers would be exercised under the "guidance" of white missionaries. The Foreign Mission Committee of the Free Church of Scotland supported Stewart's views and Govan resigned.

\subsection{Rev Dr James Stewart (1870-1905)}

While Stewart favoured a broader approach to education than Govan, essentially their aims coincided. His educational programme was fourfold: "to train young men who had a strong spiritual and intellectual capacity as preachers" (White 1987:4); to train black school teachers; to offer vocational training and a general education. Stewart continued to operate with Govan's principles of non-denominationalism, racial integration, high standards and conversion (A Smith, Appendix to Lovedale Missionary Institution [LMI] Jubilee Report 1891:iii). Its ecumenical stance was clear: "it may not be generally known how 
widespread and unsectarian its operations are", for "Lovedale's doors stand wide open, and nothing shuts out any, white or coloured, boys or girls, full grown men or little children" (Lovedale Missionary Institution [LMI] Report 1885:5). The denominational composition of the student body at Lovedale was demonstrated in a Congregational Union of South Africa report on ministers (1884). It referred to ministers of the Congregational Union, the Free Church Mission and the United Presbyterian Church Mission, but did not include details of Anglicans and Methodists (LMI Report 1884:6). From time to time, candidates of the Dutch Reformed Church were also trained at Lovedale (LMI Report 1894:19). As the result of Stewart's initiative, the Congregationalists appointed a tutor in 1885 in the person of Rev T Durant Philip.

With regard to standards, the biblical languages continued to be mandatory for theological students (LMI Report 1878:6), despite Stewart's low estimate of their value: "even this small amount of classical learning is forced upon us against our wish and better judgement" (LMI Report 1883:5). For him, English was now the "classical" language. The Free Church and many blacks disagreed with Stewart. Black students considered the deprivation of classical and biblical languages to be a sign of their own inferior status and of racism. Stewart considered the three-year literary course to be equivalent to a BA degree. This was virtually the course which Scottish ministers followed in their training. In this way he maintained the standards set by Govan, despite his apparent differences in educational philosophy. However, both shared the same general aim which was "the evangelisation of the heathen and the building up of a Native Christian Church" (LMI Report 1892:3) through education. Stewart was to achieve this aim, though, not in the manner he quite expected (see below). High standards may also have been a contributory factor in the constant low numbers of candidates who enrolled for theological courses. In 1877 there were eleven candidates, of whom only 5 completed the year (LMI Report 1877:8). Prior to the suspension of the course, concern was expressed concerning the low numbers of candidates (LMI Report 1902:19).

The year 1892 witnessed the introduction of a re-organised theological course. Few actual changes were made except that an emphasis was laid on the history and content of the Bible in English and the discipline of apologetics was discontinued in favour of dogmatics. Perhaps this was due, in part at least, to the rise of liberal theology and biblical criticism in Europe, and the fear that it might come to influence students of theology. There was a concern for "the negative influence of criticism" and its potential to be "destructive to their faith" (LMI Report 1892:27). 
The greater concern, however, was with the methodology of the course. "The nature of the subjects they have been studying is such as to make demands more upon the memory and understanding, than upon the Reflective Powers of the mind, but it still furnishes abundant food for such Reflection" (LMI Report 1893:32). This comment reveals the weakness of the "banking" method of education where leaders in the Christian community may well be able to repeat parrot fashion what they have been taught, but unable to enter into discussion of that same content persuasively and so convince the unchurched of the worthiness of the Gospel. The systematic approach to theology was found to be wanting in effectiveness. The approach that seemed to yield better results was "more conversational than methodical" (LMI Report 1893:33), and practical. This was especially true of the preparation of evangelists, who were generally more mature in years. Rev John Lennox, tutor, commented: "What they lacked in nimbleness of mind, was compensated by the power of appreciation, born of their own former experience of evangelistic work" (LMI Report 1894:31). Here was the raison d'etre for the conversational method!

However, Stewart had a generally low, though at times contradictory, opinion of the capabilities of black candidates. He could say of missionary agents: “.. as the standard of success, things are hardly yet within sight of what we hope they will one day be", while at the same time "there never has been a year so remarkable for promise as the present" (LMI Report 1875:3). His problem seemed to be the fulfillment of potential. This was in line with his general view "that Africans usually reach a maximum, and that a rather low one, is an undoubted fact" (LMI Report 1875:5). The drive to maintain standards led him to introduce a preparatory theological course in 1901 (LMI Report 1875:20) and to insist on stringent trials prior to ordination. Hence he aimed to train preachers "who may after considerable trial be found fitted by their mental qualification and general [Christian] character" (LMI Report 1873:3) which was considered to be "the end of missionary education" (LMI Report 1890:6). However, he was reluctant to ordain, even those who had completed the three year theological course "without regular ordination" (LMI Report 1873:6) or "without expecting ordination to a charge" (LMI Report 1872:5).

Yet, Stewart's approach was tempered by the reality of his situation. Due to doubts concerning the supply of missionaries from Scotland for the future, he realised "an urgent need for raising up a Native Ministry" (LMI Report 1879:5). Rather than consider the ordination of more black ministers, he introduced a new six year long course for Native Preachers and Evangelists. In 1891 a one year evangelists' course was introduced. In order to further increase the 
numbers of lay workers Stewart proposed that "intending teachers ought to receive a measure of theological training to qualify them to act as Evangelists. Christian teachers so trained would be a power for good in a heathen community" (LMI Report 1879:5). By this means of expanding the ranks of alternative forms of ministry, he could successfully restrict access to the ordained ministry.

Stewart subscribed to a contemporary separatist approach, and this may well have been a contributory factor, along with the maintenance of high standards, in the ordination of so few pastors. Between 1856 and 1910 less than twenty-five pastors were ordained among black Presbyterians. Switzer (1993:125) suggests that this was due to the fact that "missionary enthusiasm for ordaining African pastors was on the wane by the 1880s, as the arbiters of a segregationist culture began to separate church congregations and limit contact between white and black clergy".

Consequently, the imminent rise of the secessionary movement was to demonstrate how deeply black pastors felt concerning their being kept in subordinate roles and denied equal status (i.e. ordination) and opportunities with their white counterparts. Stewart himself suffered the personal indignity of his protégé and colleague, Rev Mpambani J Mzimba, seceding from the Free Church of Scotland Mission. Mzimba had been one of the first black ministers trained at Lovedale to be ordained, along with Elijah Makiwane in 1875 (LMI Report 1875:6). They had completed the theological course with a Congregationalist, James van Rooyen, who went to do missionary work with the London Missionary Society (LMS). After seceding with a large section of his congregation at Lovedale, Mzimba formed the Presbyterian Church of Africa in 1898. Perhaps the system of theological education at Lovedale had prepared its candidates for leadership positions in the church too well! Yet, it was unfortunate that some had to leave the Mission to demonstrate and realise their leadership potential.

\subsection{Rev Dr James Henderson (1906-1930)}

As we have seen above, there was a real sense of continuity in the policies of William Govan and James Stewart. That sense was even greater between Stewart and James Henderson, his successor. Henderson's entire work, in continuity with his predecessors, was governed by a strong sense of the need to develop Christian character as a prerequisite for Christian leadership. This process was also part of Govan and Stewart's programme. He was committed to a "character ethic" described by Covey (in Kretzschmar 2002:54) as consisting of "integrity, humility, fidelity, temperance, courage, justice, patience, industry, simplicity, modesty and the Golden Rule [do unto others ...]". Shepherd (1971:71) aptly commented: "He believed that the steady discipline of 
the Institution, its spiritual influence and ideals, its claims upon obedience and self-restraint, were performing great service in the upbuilding of character."

One of the few developments he introduced was where he initiated a new scheme for the training of evangelists and Bible women. He recognised the valuable role women were already playing in the furtherance of the Gospel. Evangelism had been fundamental to the establishment of Lovedale. Shepherd (1971:97) has captured the significance of the development of indigenous leadership: "It was recognized that for the evangelisation of the African, trained Africans must be secured, for they knew as no other the intricacies of the African mind and could appeal with power to the African heart."

It is instructive to note how many of those who trained for the ordained ministry exercised their leadership skills beyond the confines of the church context. A number of Christians and ordained ministers were amongst the founders of the South African Native National Congress in 1912. Their mission education had prepared them well for leadership both within the church and in the wider community according to the following (Oosthuizen 1973:779):

"Practically all the most influential political leaders in Africa went through the Christian mission or church schools. It is no wonder that even Africans regard the Church as the 'guardian angel' of African nationalism and that the Church has laid 'secure political foundations' for African nationalism."

If you look as far back as the time of the formation of the ANC in 1912, the leaders there were ... people that had been trained in the Mission Schools in the first instance (Meyer 1999:48).

The work of the Theological Department, which had been suspended for ten years, was restarted in 1913. The course lasted for four years and had six students. Under the continuing able direction of Rev John Lennox, theological tutor, theological studies were given a more contextual emphasis: "One is tempted to advocate boldly that with students at the stage of these Native men the logical completeness of Systematic Theology should be abandoned in favour of a more incidental [contextual] but living discussion of Christian truth as it arises in a comprehensive study of the Scriptures" (LMI Report 1915:34). Lennox had earlier expressed his belief in the value of the prior learning experiences of candidates for the ministry, especially those who were older and had considerable experience of Christian work. Written during the First World War, his views were apposite for the training of ministers whose ordained colleagues were rendering sterling service in the war 
zone. The situation which Lennox sought to address creatively was, and still is today in many African institutions, the situation where "theology produced elsewhere is still being studied and taught in a non-reflexive way, without the teachers and students appropriating theological truths within their own context and creating new knowledge, insights and applications" (Kretzschmar 2002:55). "The ultimate value of contextualisation for us is that it is in the very particularity of its interpretation in specific situations that the gospel achieves a universal application" (Duncan 1997:8). This is the approach which moves from the local to the global (Saayman 1995:191):

"Contextualisation places more emphasis on the specific contexts of people, than on the universal. The supposition behind this is the conviction that it is in being fully true to one's particular locality (the total context), that one can also be fully true to the universality of the Christian community."

In 1916, due largely to the vision of James Stewart and the energy of James Henderson, the South African Native College was established on land adjacent to Lovedale at Fort Hare. Due to the war situation, the new preparatory course for theological education which began at the South African Native College in 1917, returned to Lovedale in 1918. Theological education was again transferred to the College in 1920 with the opening of a Presbyterian Hostel with Rev John Lennox, theological tutor, as Warden. So ended the formal connection of Lovedale with theological education, though informal contacts would remain into the future.

\section{COMPARISON AND CONCLUSION}

In conclusion and by comparison some basic remarks have to be made. Each of the two institutions under discussion here had their own clear principles and emphases as well as their own history of establishment, consolidation, self-examination and change. These processes which in some cases were opposed to one another (denominationalism at Pretoria versus non-denominationalism at Lovedale, racially separate at Pretoria versus racially integrated at Lovedale, but fortunately in both cases striving for high academic standards and proper education) were defined by their own particular contexts. It is however clear that both institutions grew in size, influence and stature.

Secondly, it is clear that they forged and maintained close links with the denominations or confessional bodies which they served, but also that they developed in the course of time a greater ecumenical nature and openness though at a different pace. 
Thirdly, it is interesting to note that the standard and quality of theological education in the course of their respective histories generally speaking was on the rise. A greater openness to various research traditions developed in the course of time as well as a greater awareness for contextualisation.

Fourthly, it has to be stated that both institutions in a way neglected their own historical and theological traditions, the Pretoria faculty more so than the Lovedale institution. In the postmodern era the emphasis was more and more put on the pragmatic needs of the church and effectiveness, and less and less on a solid theology operating with real biblical, historical and doctrinal roots.

Fifthly, these two institutions maintained close links with the contexts of their times, whether it was the colonial or post-colonial and apartheid or post-apartheid South Africa. Strong leadership, regardless of the context came from both these two institutions with regard to societal issues, sometimes agreeing and sometimes inherently opposing current systems of their times.

In the sixth instance the two institutions provided relatively strong theological and ecclesiastical leadership to the churches they were serving. Representatives from the two institutions at various stages took up leadership in the churches or otherwise provided their churches with theological and/or prophetic indicators as regards the road ahead. Whether these institutions always succeeded in providing the churches with a core of strong ministerial leadership is another question.

Finally, and in conclusion, it must be said that the role of these two institutions in furthering the cause of church, society and Kingdom of God cannot be underestimated. In the history of the churches and of theological leadership in South Africa the names of Lovedale and of the Pretoria Faculty of Theology will for many years to come remain prominent entities.

\section{Consulted Literature}

Abrahams S, Punt, J \& Williams DT (eds) 1997. Theology on the Tyumie. Cape Town: David Philip.

Bredekamp H \& Ross R (eds) 1997. Missions and Christianity in South African History. Johannesburg: Witwatersrand University Press.

Christian Express, 1906, 36:425.

Duncan G A 1997. Scottish Presbyterian Church Mission Policy in South Africa, 1898-1923. (MTh dissertation). Pretoria: University of South Africa.

-, 2000. Coercive Agency: James Henderson's Lovedale, 1906-1930. DTh thesis. Pretoria: University of South Africa.

Groenewald E P 1980. Die wordingsjare van die Teologiese Fakulteit, in: A C Barnard (e a). Teologiese pleiding in teorie en praktyk. Pretoria: NG Kerkboekhandel, 14-32. 
Hofmeyr J W 1971. ' $n$ Geskiedenis van die Teologiese Fakulteit van die N G Kerk aan UP 1938-1970 (Ongepubliseerde Proponentskripsie).

Kretschmar L 2002. Authentic Christian Leadership and Spiritual Formation in Africa. Journal of Theology for Southern Africa 113 (July), 41-60.

Lovedale Missionary Institution Annual Reports (1870-1923).

Meyer W H 1999. Christianity and the Bible in South African life and literature: Interviews with Mandla Langa and Wally Serote. Bulletin for Contextual Theology 4 (3, February): 5-51.

Mills W G 1997. Missionaries, Xhosa Clergy and the Suppression of Traditional Customs in: Bredekamp \& Ross (eds), 153-172.

Oosthuizen G C 1973. Black Theology in Historical Perspective. South African Journal of African Affairs, 3:77-94.

Saayman W 1995. Christian Mission History in South Africa. Missionalia 23 (2, August): 184-200.

Shepherd R H W 1940. Lovedale, South Africa: The story of a century. Lovedale: Lovedale Press.

-, 1971. Lovedale, South Africa: 1824-1955. Lovedale: Lovedale Press.

South African Outlook 54:647.

Stewart J 1906. Dawn in the Dark Continent: Or Africa and its missions. Edinburgh: Oliphant, Anderson \& Ferrier.

Switzer L 1993. Power and Resistance in an African Society:The Ciskei Xhosa and the making of South Africa. Pietermaritzburg: University of Natal Press.

Van der Watt P B (red) 1989. Deo Gloria Teologiese Fakulteit 1938-1988. Pretoria: NG Kerkboekhandel.

Wethmar C J 2000. Theological education in an ecumenical context: principles and procedures of the Pretoria model. Skrif en Kerk 21(2): 416-428.

White T R H 1987. Lovedale, 1930-1955: The study of a missionary institution in its social, educational and political context. Unpublished MA dissertation, Grahamstown: Rhodes University. 